\title{
MODEL NUMERIK TRANSPOR SEDIMEN DASAR DAN PERUBAHAN MORFOLOGI DASAR SUNGAI TIBO, KABUPATEN DONGGALA
}

\author{
Nurnaningsi ${ }^{*}$, Yutdam Mudin ${ }^{*}$, Abd. Rahman*). \\ ${ }^{*}$ Jurusan Fisika,Fakultas Matematika dan Ilmu Pengetahuan Alam, Universitas Tadulako
}

Email: Nurnaningsi37@gmail.com

\begin{abstract}
Research has been carried out on numerical models of beadload sediment transport and morphological changes in the Tibo River, Donggala District. This study aims to analyze the silting process based on the results of numerical modeling of the rate of morphological changes at the mouth of the Tibo River. This modeling has used data from measurements at research sites such as river discharge and downstream deposits from the Tibo River. In addition, data have been used: bathymetry, tides and wind speed. The results showed that the current velocity at the Tibo River estuary was $0.001-0.05 \mathrm{~m} / \mathrm{s}$. When at low tide, the sediment concentration spreads wider in the sea area than in the full moon tide. Sediment distribution tends to go west after the simulation on the 15th day. The siltation potential also occurs based on the simulation results, where there is siltation of water from 4.2 to $4.4 \mathrm{~cm}$.
\end{abstract}

Key words: River, Sediment, Siltation

\begin{abstract}
ABSTRAK
Penelitian telah dilakukan pada model numerik transportasi sedimen beadload dan perubahan morfologi di Sungai Tibo, Kabupaten Donggala. Penelitian ini bertujuan untuk menganalisis proses pendangkalan berdasarkan hasil pemodelan numerik dari laju perubahan morfologis di mulut Sungai Tibo. Pemodelan ini telah menggunakan data pengukuran di lokasi penelitian seperti debit sungai dan sedimentasi dari hilir Sungai Tibo. Selain itu, telah digunakan data-data: batimetri, pasang surut dan kecepatan angin. Hasil penelitian menunjukkan bahwa kecepatan saat ini di muara Sungai Tibo adalah 0,001-0,05 m / s. Ketika pada saat air surut, konsentrasi sedimen menyebar lebih luas di wilayah laut dari pada pasang purnama. Distribusi sedimen cenderung ke barat setelah simulasi pada hari ke-15. Potensi pendangkalan juga terjadi berdasarkan hasil simulasi, dimana terdapat pendangkalan air sekitar 4,2 sampai 4,4 cm.
\end{abstract}

Kata Kunci: Sungai, Sedimen, Pendangkalan 


\section{PENDAHULUAN}

Angkutan sedimen (sediment transport) merupakan komponen dari aliran sungai pada yang memiliki faktor penting dalam perubahan morfologi dasar perairan sungai. Besar angkutan sedimen tergantung dari kondisi geografis, lingkungan, tutupan lahan, dan kondisi geologi dari Daerah Aliran Sungainya. Jika angkutan sedimen sungai sangat tinggi maka akan terjadi penumpukan material di badan sungai dan akan membentuk suatu daerah kering yang diklasifikasikan sebagai delta (Ali Mulerli 2010).

Aliran sedimen di sepanjang sungai terdiri dari material hasil erosi yang memiliki hubungan erat dengan faktor gesekan, laju sedimentasi dan konfigurasi geometri yang diasumsikan sebagai bentuk permukaan dasar sungai. Butiran sedimen sebagai salah satu faktor yang berpengaruh dalam membentuk dasar sungai adalah parameter yang digunakan dalam studi ini.

Selain faktor alam, faktor kegiatan manusia seperti kegiatan penambangan pasir telah menyebabkan angkutan sedimen disungai menuju muara. Di Sungai Tibo, terdapat dua perusahaan yang telah melakukan kegiatan penambangan pasir. Kegiatan tersebut telah memberikan dampak terhadap peningkatan ekonomi masyarakat sekitarnya. Akan tetapi secara bersamaan telah memberikan dampak terhadap lingkungan baik lingkungan fisik kimia biologi. Salah satu dampak negatif yang berpotensi terjadi adalah perubahan morfologi sungai dalam bentuk pendangkalan (perubahan batimetri) sehingga terjadi pelebaran badan sungai. Perubahan batimetri ini diakibatkan oleh material yang terangkat oleh aktivitas tambang dan dibawah arus sungai ke muara. Dengan demikian diduga bahwa selama ini selalu terjadi proses pendangkalan di muara Sungai Tibo. Oleh karena itu simulasi numerik tentang perubahan morfologi dasar sungai akan mampu memberikan informasi tentang potensi dampak kerusakan lingkungan.

\section{METODE PENELITIAN}

Lokasi penelitian ini adalah di perairan Sungai Tibo dan sekitarnya. Dalam hal ini di Desa Tibo Kecamatan Sindue Tombusabora Kabupaten Donggala.

Sebelum melakukan pengukuran, terlebih dahulu dilakukan survey pendahuluan untuk memperolah gambaran lokasi penelitian untuk menentukan batas lokasi terluar (boundary) dan menentukan lokasi pengambilan sampel data yang dibutuhkan dalam pemodelan numerik.

Data pasang surut yang digunakan pada penelitian diperoleh dari Stasiun di 
Pelabuhan Nasional Pantoloan. Data pasang diolah dengan menggunakan metode admiralty untuk menentukan tipe pasang surut suatu perairan melalui perhitungan bilangan Formzahl:

$$
F=\frac{K 1+O 1}{M 2+S 2}
$$

Data angin yang digunakan diperoleh dari Stasiun Badan Meteorologi kelas II Mutiara Palu.

Pengukuran konsetrasi sedimen di bagian hilir diperoleh melalui alat perangkap sedimen. Debit aliran sungai diperoleh dengan menghitung luas penampang sungai dan kecepatan arus aliran sungai seperti pada persamaan (2):

$$
Q=A \cdot V
$$

Langkah awal membangun simulasi adalah membuat lokasi daerah penelitian dengan mendigitasi data batimetri dalam bentuk titik-titik kedalaman. Kemudian membuat file geometri berdasarkan data batimetri yang sudah tersedia. File geometri ini adalah file batimetri yang telah dibuat grid dalam bentuk jaring-jaring elemen (mesh). Selanjutnya membuat boundary condition yaitu input untuk data pasang surut dan data debit serta atur sifat material seperti turbulensi, kekasaran, dan input data angin. Proses ini dilakukan dengan menggunakan modul RMA2 yang terdapat dalam perangkat lunak Surface Water Modeling System 10.1 (SMS) proses running RMA2 akan menghasilkan pola arus.

Hasil dari RMA2 akan menjadi input di modul SED2D ditambahkan dengan nilai konsentrasi seimen yang telah dihitung. Hasil running dari SED2D adalah sebaran sedimen

\section{HASIL DAN PEMBAHASAN}

\section{Gelombang Pasang Surut}

Berdasarkan hasil analisa pasang surut dengan metode admiralty maka telah diperolah nilai amplitudo 9 (sembilan) komponen pasang surut antara lain komponen $\mathrm{M} 2=35,6 \mathrm{~cm}, \mathrm{~S} 2=47,9 \mathrm{~cm}, \mathrm{~N} 2=4,8$ $\mathrm{cm}, \mathrm{K} 2=12,9 \mathrm{~cm}, \mathrm{~K} 1=78,3 \mathrm{~cm}, \mathrm{O} 1=35,1 \mathrm{~cm}$, $\mathrm{P} 1=25,8 \mathrm{~cm}, \mathrm{M} 4=3,5 \mathrm{~cm}$, dan $\mathrm{MS} 4=17,0 \mathrm{~cm}$. Nilai amplitudo komponen pasang surut M2, S2, K1, dan O1 dibutuhkan dalam perhitungan bilangan Formzahl. Bilangan Formzahl digunakan untuk memenentukan tipe pasang surut suatu perairan. Perairan Desa Tibo memiliki bilangan Formzahl sebesar 0,98 yang dihitung menggunakan persamaan 1. Besarnya bilangan Formzahl tersebut mengindikasikan pasang surut di perairan Desa Tibo memiliki tipe campuran condong harian ganda (mixed side prevailing semidiurnal) dimana terjadi dua 
kali air pasang dan dua kali air surut dalam sehari, tetapi tinggi dan periode pasang surutnya berbeda.

\section{Angin}

Angin di perairan Sungai Tibo dominan menuju arah Utara dengan presentase kejadian $30 \%$ yang didominasi dengan kecepatan 2,057 m/s. prosentase kejadian dan arah angin dapat dilihat pada Gambar 1:

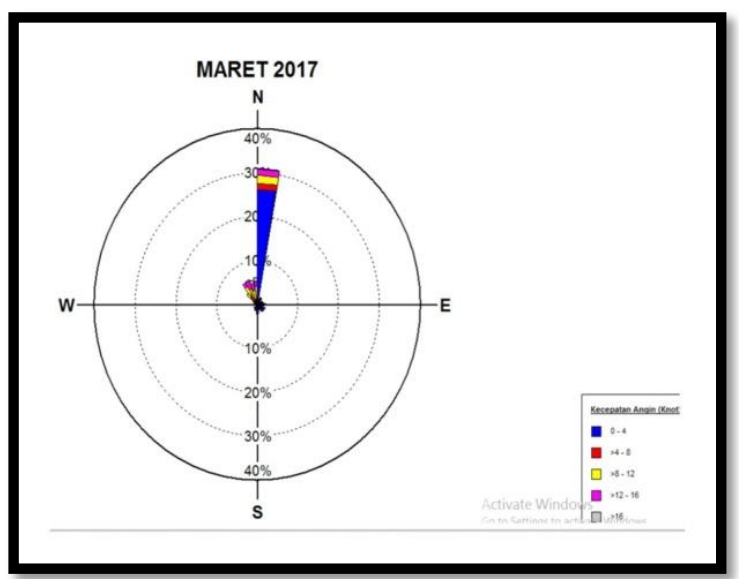

Gambar 1. Diagram angin permukaan bulan maret 2017 di muara Sungai Tibo dan sekitarnya

\section{Pola Arus}

Hasil simulasi model 2D merupakan gambaran dari pola arus yang terjadi di lokasi penelitian. Dalam hal ini diskenariokan pola arus pada keadaan Pasang tertinggi (pasang maksimum) dan surut terendah (surut minimum). Kedua keadaan tersebut memiliki pergerakan arus yang berbeda dari arah arus maupun kecepatannya. Perbedaan karakteristik tersebut ditinjau berdasarkan kondisi pasang surut yaitu pasang maksimum, surut minimum, menuju pasang, dan menuju surut. Analisis hasil pemodelan arus pada penelitian ini berupa bentuk pola arah dan kecepata arus laut. Pola arus digambarkan dalam bentuk vektor arah arus yang berupa anak panah. Besar kecilnya anak panah dan gradasi warna memberikan nilai besar kecilnya kecepatan arus.

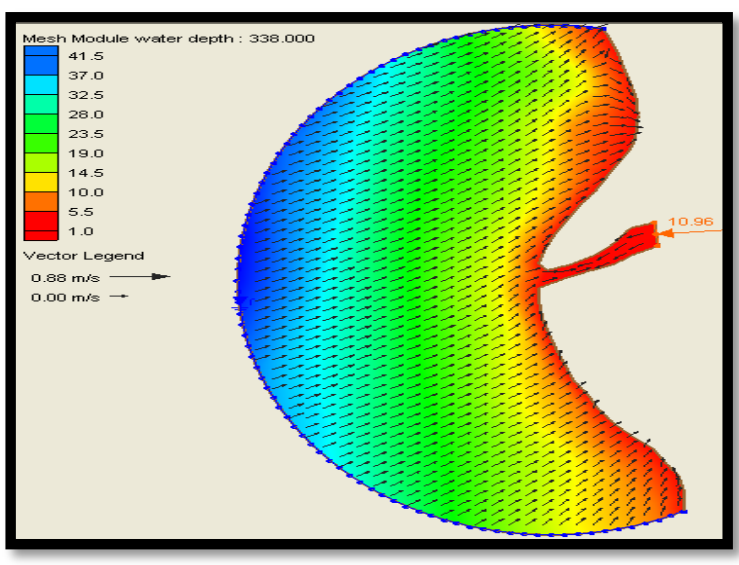

Gambar 2. Pola pergerakan arus saat menuju pasang

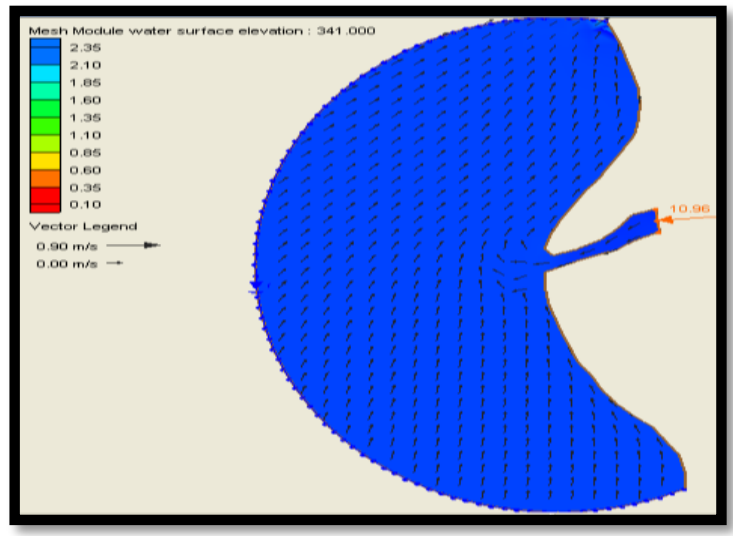

Gambar 3. Pola pergerakan arus saat pasang tertinggi 


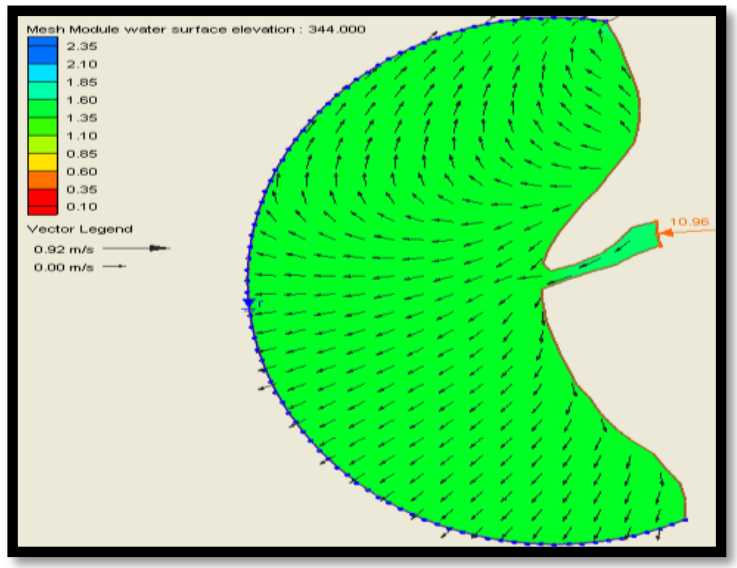

Gambar 4. Pola pergerakan arus aat menuju surut

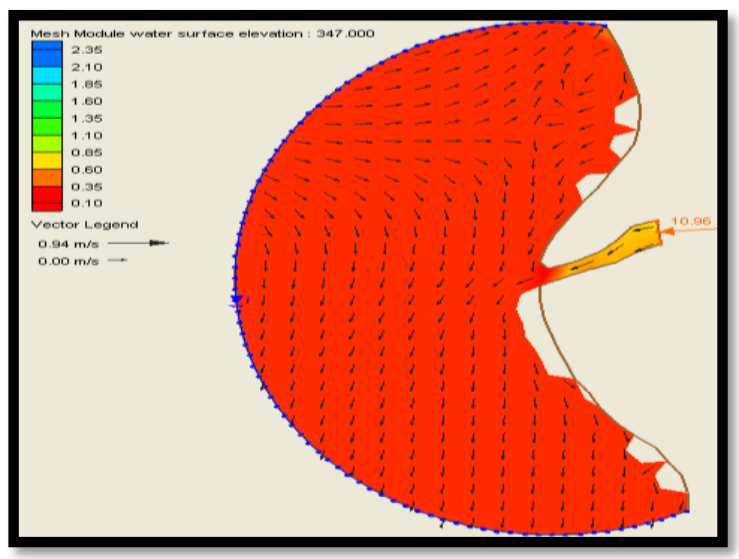

Gambar 5. Pola pergerakan arus saat surut terendah

Pengaruh dari pasang surut terhadap pola pergerakan arus tersebut dapat dilihat dari arah arus yang saling bertolak belakang antara saat posisi menuju surut dan menuju pasang. Ketika pasang surut pada posisi menuju surut terjadi pengurasan air laut (waktu kuras) sehingga arah arus terlihat keluar menjauhi daratan sedangkan saat menuju pasang terjadi pengisian air laut sehingga arah arus terlihat menuju ke arah daratan. Kacepatan arus maksimum terjadi pada saat menuju pasang dan menuju surut sedangkan kecepatan arus minimum terjadi pada saat pasang tertinggi dan surut terendah dimana kecepatan arus hampir mendekati nol.

Selain faktor pasang surut,pola arus permukaan diperairan Desa Tibo juga dipengaruhi oleh faktor batimetri, hal tersebut dapat dilihat dari perubahan arah arus permukaan yang bervariasi mengikuti nilai batimetri. Sehingga terlihat bahwa pola pergerakan arus selama 15 hari waktu simulasi disebagian pinggiran pantai terdapat wilayah yang kering (tidak ada arus). Hal ini disebabkan karena adanya perubahan batimatri dengan nilai kedalaman yang sangat kecil, sehingga pada kondisi surut minimum wilayah tersebut terlihat kering. Kecepatan arus pada kondisi ini sangat kecil yaitu kurang dari $0,001 \mathrm{~m} / \mathrm{s}$ atau sama dengan nol. Nilai arus sekecil ini berpotensi terjadinya sedimentasi.

Angin disekitar perairan Desa Tibo dominan berasal dari arah utara dan ada juga yang berasal dari arah timur laut sehingga perubahan arah arus dan kecepatan arus sangat bervariasi. 


\section{Proses sedimentasi}

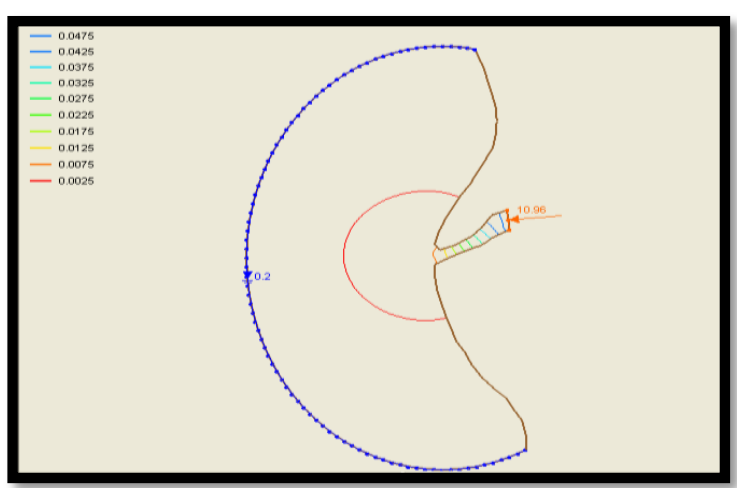

Gambar 6. Konsentrasi sedimen saat air laut dalam kondisi surut

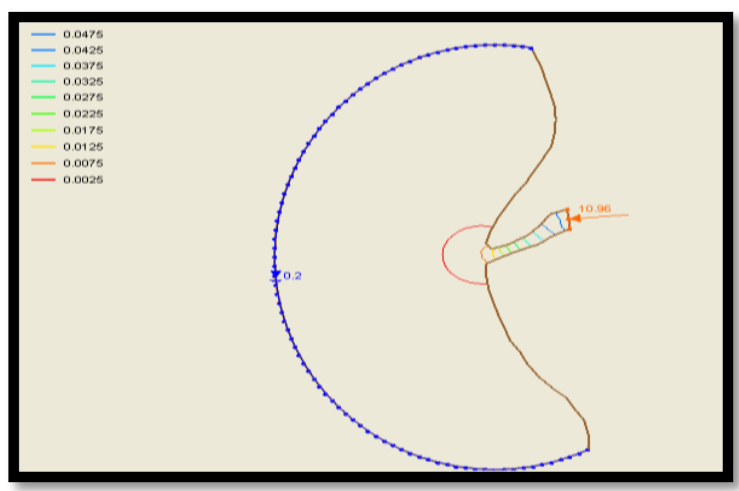

Gambar 7. Konsentrasi sedimen saat air laut dalam kondisi pasang

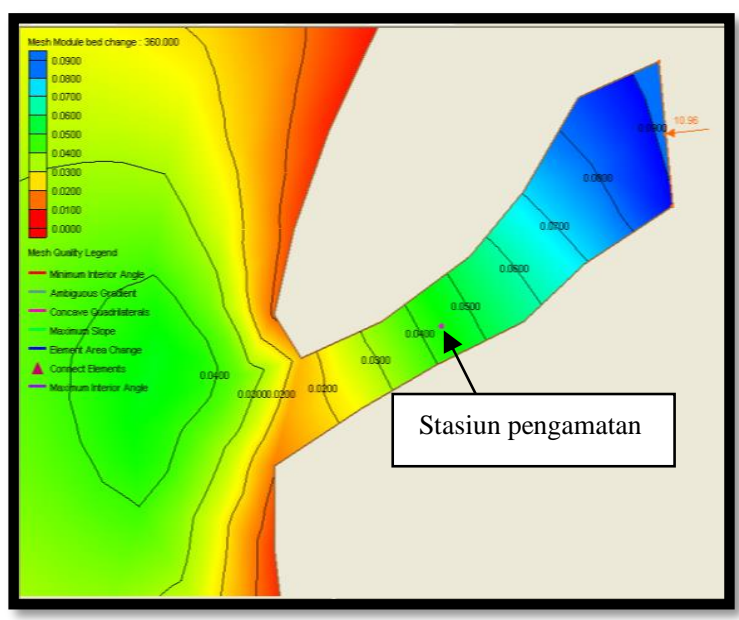

Gambar 8. Perubahan batimetri diperairan Sungai Tibo

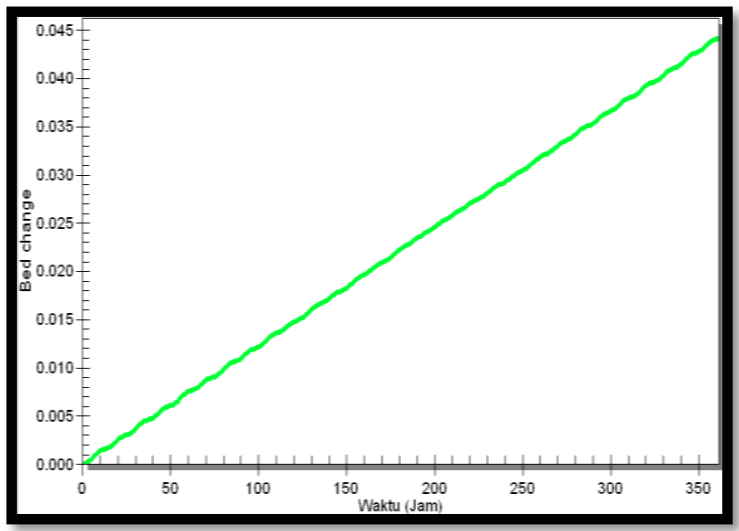

Gambar 9. Grafik perubahan batimeri diperairan sungai Desa Tibo dalam waktu simulasi 15 hari.

Simulasi transpor sedimen ini mengasumsikan bahwa sumber sedimen yang masuk ke lokasi penelitian berasal dari sungai sebesar $0.09 \mathrm{gr} / \mathrm{liter}$.

Gambar 6 dan Gambar 7 memperlihatkan konsentrasi sedimen pada kondisi surut dan kondisi pasang. Saat surut konsentrasi sedimen menyebar lebih luas diwilayah lautan dibandingkan saat pasang. Hal ini disebabkan karena saat air laut pada kondisi surut, sedimen yang berasal dari sungai ikut terbawa oleh air sungai menuju muara dan terbawa oleh air laut saat air laut bergerak menjauhi muara, dan pada saat pasang konsentrasi sedimen terlihat lebih kecil disebabkan sedimen yang sebelumnya ikut terbawa air laut saat surut terdorong kembali masuk kedalam sungai oleh air pasang yang menuju kedarat.

Berdasarkan skenario pemodelan numerik konsentrasi sedimen dasar terangkut dibagian sungai hingga muara 
sebesar 0,007 gr/liter - 0,047 gr/liter, dan konsentrasinya menurun pada perairan yang semakin jauh dari sungai hingga 0,002 gr/liter.

Hasil simulasi numerik selama 15 hari menunjukkan perubahan batimetri yang berpotensi terhadap pendangkalan sungai, dimana pendangkalan terjadi distasiun pengamatan pada Gambar 8 berkisar hingga 4,4 cm. Pendangkalan juga terjadi di mulut sungai hingga muara Sungai Tibo.

Untuk dapat mengetahui laju pendangkalan perairan Sungai Tibo yang diakibatkan oleh sedimentasi, maka Gambar 9 menunjukan nilai perubahan dasar perairan (bed change) terhadap waktu pada titik stasiun pengamatan.

Hasil pemodelan telah menunjukan bahwa besarnya pendangkalan di stasiun pengamatan (Gambar 8) sekitar 4,4 cm per 15 Hari atau sekitar $8,8 \mathrm{~cm}$ per bulan. Dengan demikian, berdasarkan nilai ratarata bulanan maka dalam 1 (satu) tahun akan berpotensi terjadi pendangkalan dimuara sungai kurang lebih sekitar 105,6 $\mathrm{cm}$.

Dengan demikian, berdasarkan Gambar 8 dan gambar 9 yang memperlihatkan telah terjadinya pendangkalan disekitar perairan Sungai Tibo telah menunjukkan bahwa model numerik pada penelitian ini sudah dapat menghubungkan antara parameter transpor sedimen dasar terhadap perubahan morfologi dasar sungai dengan sangat baik

\section{KESIMPULAN}

Berdasarkan hasil penelitian mengenai model karakteristik sedimen terhadap perubahan morfologi dasar muara sungai tibo maka dapat disimpulkan bahwa:

1. Pola pergerakan arus 2 Dimensi di perairan sungai tibo sangat bervariasi dengan arah aliran dan kecepatan yang berubah terhadap waktu (menuju pasang, pasang maksimum, menuju surut dan surut minimum). Pada saat menuju pasang massa air cenderung memasuki muara, dan sebaliknya pada saat surut massa air meninggalkan muara. Secara keseluruhan kecepata arus diperairan Sungai berkisar $0,001 \mathrm{~m} / \mathrm{s}-0,05 \mathrm{~m} / \mathrm{s}$.

2. Sebaran konsentrasi sedimen pada kondisi menuju surut lebih besar dibandingkan sebaran konsentrasi sedimen pada kondisi pasang. Hal ini disebabkan karena pada saat menuju surut konsentrasi sedimen ikut terbawa oleh air laut hingga menjauhi muara, dan pada saat menuju pasang konsentrasi sedimen ikut terdorong kembali msuk kedalam muara.

3. Perubahan nilai batimetri yang menyebabkan perubahan morfologi 
dasar Sungai Tibo berpotensi terhadap terjadinya pendangakalan, yaitu sekitar $105,6 \mathrm{~cm}$ per tahun.

\section{DAFTAR PUSTAKA}

Anasiru Triyanti, (2006), Angkutan Sedimen Pada Muara Sungai Palu, Palu, Universitas Tadulako.

Arsyad, S., (1989), Konservasi Tanah dan Air, Bogor, Institut pertanian Bogor Press.

Barbara, P., (2008), User Guide To SED2D Wes Version 4.5, US Army, Engineer Research and Development Center Waterways Experiment Station Coastal and Hydraulics Laboratory, USA.

Barbara, P., (2009), User Guide To RMA2 Wes Version 4.5, US Army, Engineer Research and Development Center Waterways Experiment Station Coastal and Hydraulics Laboratory, USA.

Chay Asdak, (1995), Hidrologi dan Pengelolaan Daerah Aliran Sungai, Gajah Mada University Press, Yogyakarta.

Ilahude, A.G., (1999), Pengantar Keoseanologi Fisika, LIPI.

Mulerli Ali, (2010), Dampak Angkutan Sedimen Terhadap Pembentukan Delta di Muara Sungai Bone, Puslitbang Sumber Daya Air, Bandung.

Mulyanto,H.R., (2007), Sungai Fungsi \& Sifat-sifatnya, Graha Ilmu, Yogyakarta. Pinet, (1992), Oceanography: An

Introduction to The Planet Oceanus, West Publishing Company, New York.
Rifaldi, (2012), Ekologi Sedimen Laut Modern, Pekanbaru, UR Press

Soewarno, (1991), "Hidrologi", Penerbit

Nova, Bandung.

Triatmodjo, B., (1999), Teknik Pantai, Beta Offset, Yogyakarta.

Yuwono, N., (1994), Perencanaan Bangunan Jetti, Laboratorium Hidraulika dan Hidrologi. PAU-ITUGM, Yogyakarta. 